\title{
Research article: Convergence led livelihood security: A case study in Chittoor district of Andhra Pradesh
}

Article Chronicle: Received : 02.08.2017;

Revised : 01.09.2017; Accepted : 18.09.2017

Key Words : Entrepreneurship, Processing, Value addition, Packing, Branding, Labeling

\section{P. SWARNA, R. PRASANNA LAKSHMI, P. BALA HUSSAIN REDDY AND P. GANESH KUMAR}

SUMMARY : Millets are small-seeded grasses that are hardy and grow well in dry areas as rain-fed crops, under marginal conditions of soil fertility and moisture. Millets have certain intrinsic quality characteristic suited for product development. The excellent and unique taste is found suitable for making variety of food products suitable for marketing. The present study was undertaken on value addition and market linkage to the various products of millets which have a commercial feasibility to enhance the income of the rural women. With this intension, the rural women of Kalikiri and Pilermandal, were extensively trained on processing, preparation of value added products, packing, branding and various possible avenues for market linkages. After acquainting with these aspects, rural women Mrs. M. Faridha, S. Thajwarsulthana and Najimunnisha with technical guidance of KrishiVigyan Kendra (KVK), Kalikiri established two small scale processing and value addition units. Registration was also done for marketing of millet value added products under Food Safety and Standards Authority of India -2006. At present, they are involved in preparation and marketing of value added millet products viz., millet biscuits, Laddu, muruku, and mixtures under a brandname of "Arogya Millet Foods" and star healthy snacks. They are marketing the products in Chittoor district and Kurnool district of Andhra Pradesh. The monthly production all the products is on an average 350 to $400 \mathrm{~kg}$ with a turnover of Rs. $70,000-80,000 /-$.

How to cite this article : Swarna, P., Lakshmi, R. Prasanna, Reddy, P. Bala Hussain and Kumar, P. Ganesh (2017). Convergence led livelihood security: A case study in Chittoor district of Andhra Pradesh. Agric. Update, 12(4): 581-586; DOI : 10.15740/HAS/AU/12.4/581-586.
Author for correspondence :

\section{P. SWARNA}

Krishi Vigyan Kendra, KALIKIRI (A.P.) INDIA Email:swarna.pillella@ gmail.com

See end of the article for authors' affiliations 